\title{
Chemical food contaminants in the initiation of cancer
}

\author{
BY ANTHONY R. TRICKER AND ROLF PREUSSMANN \\ Institute of Toxicology and Chemotherapy, German Cancer Research Center, Im Neuenheimer Feld \\ 280, D-6900 Heidelberg, Federal Republic of Germany
}

It is generally accepted that cancer incidences in various organs show strong geographical variations. Studies on immigrants show that different cancer incidences in various global regions are heavily dependent on the life-style and that the human diet is considered to be an important cause of human cancer (Wynder \& Gori, 1977; Doll \& Peto, 1981). According to our opinion, there are four major groups of carcinogenic, initiating compounds which may occur as contaminants in the human diet:

(1) polycyclic aromatic hydrocarbons ( $\mathrm{PAH}$ ) which result from the incomplete combustion of fossil fuels,

(2) mycotoxins formed as metabolic products of mould-contaminated foods,

(3) heterocyclic amines (protein pyrolysis products) formed by Maillard-type reactions during high-temperature preparation of protein-rich foods,

(4) $\mathrm{N}$-nitroso compounds which are formed by the interaction of amines and nitrosating agents such as nitrite or nitrous oxides $\left(\mathrm{NO}_{\mathrm{x}}\right)$.

To this list, several naturally occurring carcinogenic compounds (estragol, cycasin, safrole), food additives (saccharin, antioxidants such as butylated hydroxyanisole (BHA)), transition and heavy metals (arsenic, chromium, nickel, mercury) and several synthetic compounds such as dioxines and polychlorinated biphenyls (PCB) have to be included as potential human carcinogens occurring in the human diet. The following paper presents a brief overview of the occurrence of the major classes of carcinogenic food contaminants in the human diet. Whenever possible, the current situation concerning the contamination of foods in the UK is reviewed.

\section{PAH}

Contamination of foods by $\mathrm{PAH}$ results primarily from atmospheric deposition onto edible plants, by air and also from smoke-drying of foodstuffs (including tea), direct drying of cereals, smoking and grilling of foodstuffs (bacon, cheese, fish etc.) and by marine pollution of shellfish (Obana et al.1981). Early studies on the PAH contamination of foodstuffs have tended to concentrate on samples from heavily polluted environments. Dietary surveys (Santodonato et al. 1981) incorporating a large number of samples collected from polluted environments provide in our opinion biased (overestimated) evaluations of the human exposure to $\mathrm{PAH}$.

The dietary exposure to PAH in the UK has been estimated by Dennis et al. (1983) based on a total diet survey of total diet samples collected in five geographically diverse areas of the UK. The major dietary sources of PAH are summarized in Table 1. The major contributors of PAH in the UK diet are oils-fats and cereals. Although the highest individual PAH levels appear in oils-fats, their contribution to the total diet is relatively small $(5 \%)$. PAH levels in cereal and plant-based foodstuffs show considerable variation, in general the PAH levels are higher in crops grown in heavily industrialized areas 


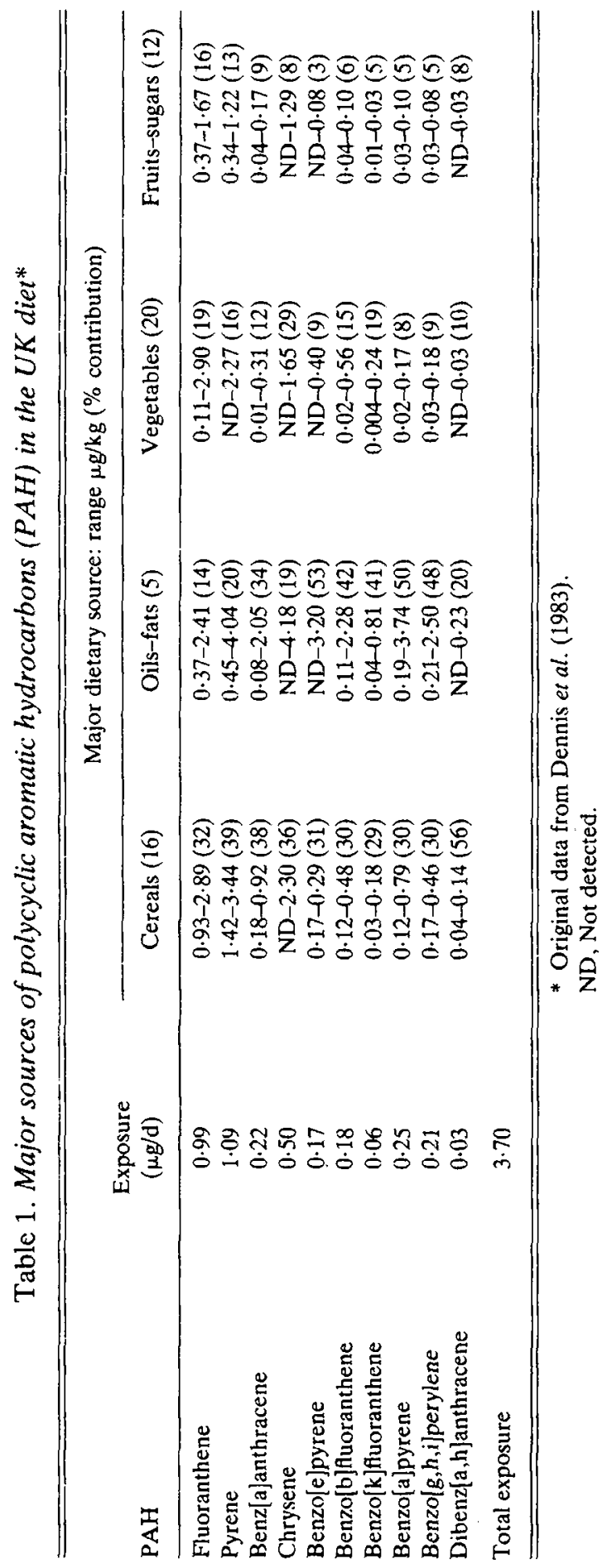


or close to major roads due to atmospheric deposition. In a review on PAH contamination of German foods, Fritz \& Soos (1981) showed that vegetables and other plant-based foods were the major dietary source of PAH.

PAH represent the most important class of carcinogens present in smoked-grilled foods or foods exposed to drying gases or atmospheric deposition, aromatic ring systems of three or more rings being more potent carcinogens than smaller ring systems.

\section{MYCOTOXINS}

Mycotoxins are an important class of over 400 naturally occurring toxic compounds produced by fungi (moulds), of which only a small minority have been shown to be toxic to mammals. Mycotoxin contamination of foodstuffs is a major problem in most tropical and subtropical countries where fungal growth is favoured by bad agricultural practice, high humidity and bad storage conditions.

Aflatoxins, a group of furanocourmarin fungal metabolites produced by Aspergillus flavus, A. parasiticus and Penicillium puberulum remains the most serious world-wide mycotoxin problem. In experimental animals, aflatoxins are potent hepatic carcinogens in rats, weak carcinogens in monkeys and inactive in mice. Aflatoxin $B_{1}\left(\mathrm{AFB}_{1}\right)$ is the most potent hepatocarcinogen known producing a $100 \%$ incidence of liver tumours in rats at a total dose of $95 \mu \mathrm{g} / \mathrm{kg}$ (Wogan \& Newberne, 1967), indicating that levels of 10 $\mu \mathrm{g} / \mathrm{kg}(10 \mathrm{ppb})$ in foods for human consumption may pose a considerable health risk. Aflatoxins $A F B_{1}, \mathrm{AFB}_{2}, \mathrm{AFG}_{1}$ and $\mathrm{AFG}_{2}$ are natural contaminants of several foods including peanuts, various tree nuts, rice, cereal grains, cassava, soya beans, peas and sorghum seed. Aflatoxins $\mathrm{AFM}_{1}$ and $\mathrm{AFM}_{2}$ (hydroxylated metabolites of $\mathrm{AFB}_{1}$ and $\mathrm{AFB}_{2}$ ) have been found in liver, milk, blood and kidneys of animals given aflatoxincontaminated feeds. The world-wide occurrence of mycotoxins in foods and animal feeds has recently been reviewed (Jelinek et al. 1989). Despite regulatory levels for aflatoxins in foods (total aflatoxins 5-20 $\mathrm{\mu g} / \mathrm{kg} \mathrm{AFB} 1, \mathrm{AFB}_{2}, \mathrm{AFG}_{1}$ and $\mathrm{AFG}_{2}$ in most countries; 10 $\mu \mathrm{g} / \mathrm{kg}$ in the UK) and animal feeds $(20-50 \mu \mathrm{g} / \mathrm{kg})$, comparatively few developing countries have managed to control the contamination to acceptable levels in susceptible commodities.

The Penicillium mycotoxin ochratoxin A (also produced by Aspergillus) is a common contaminant of cereals and other plant products at levels exceeding $1000 \mu \mathrm{g} / \mathrm{kg}$. The occurrence of ochratoxin A has been reviewed by Krogh (1980) who reported a mean level of $1035 \mu \mathrm{g} / \mathrm{kg}$ in cereals and meat products. Ochratoxin $A$ is a fairly potent carcinogen in mice inducing hepatic and renal adenomas, concomitant $\mathrm{AFB}_{1}$ exposure synergistically enhances ochratoxin A hepatocarcinogenesis (Kanisawa \& Suzuki, 1978). Patulin (produced by several species of Penicillium and Aspergillus, and by Byssochlamys nivea) is still a major mycotoxin problem in some vegetables, fruits and fruit products, in particular apple juice; however, there is some doubt about the carcinogenic potential of this compound (International Agency for Research on Cancer, 1986).

Citrinin (produced by $P$. citrinin and $P$. vividicatum) is a common contaminant of cereal grains and grain products, it often occurs as a co-contaminant in grains containing ochratoxin A. It exhibits strong nephrotoxicity, as does ochratoxin A, and induces renal tumours in rats (Arai \& Hibino, 1983). However, insufficient information is available to evaluate the human exposure to this compound.

In most developing countries, human exposure to mycotoxins still presents a serious 


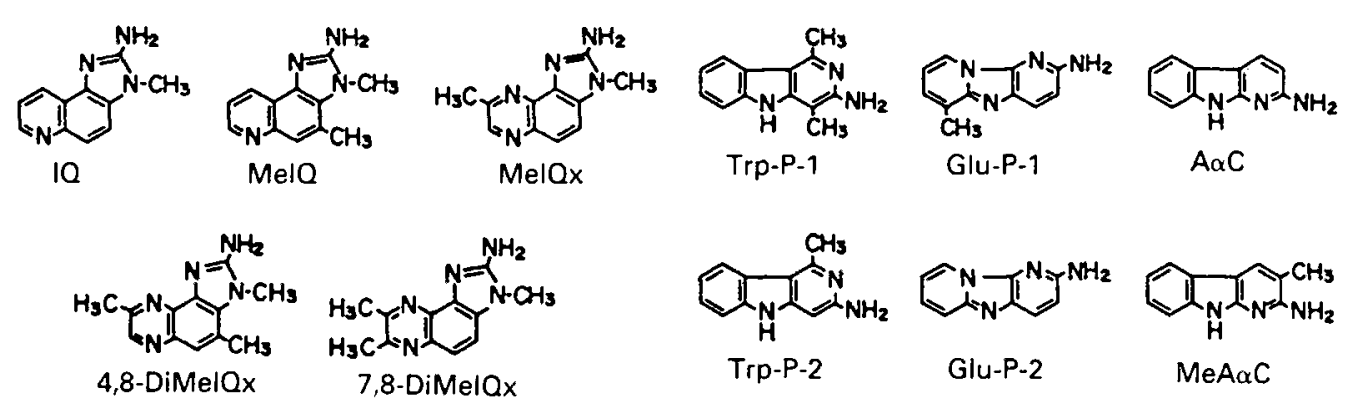

Fig. 1. Structures of some heterocyclic amines (protein pyrolysis products).

health problem as demonstrated by recent episodes of ergot alkaloid poisoning by Claviceps purpurea in Ethiopia (Demeke et al. 1979) and India (Krishnamachari \& Bhat, 1977). A positive association between $A F B_{1}$ ingestion and incidence of primary hepatocellular cancer has been reported in several countries including China, Kenya, Mozambique, Swaziland and Thailand. However, this association may be confounded by the presence of hepatitis B infection (Lutwick, 1979). Acute toxic effects due to aflatoxin exposure (estimated to be $1-6 \mathrm{mg} / \mathrm{d}$ for several weeks) has been reported in Gujurat and Rajasthan in northwestern India (Van Rensburg, 1977) and possible ochratoxin exposure in cases of Reye's syndrome (endemic Balkan nephropathy) in Czechoslovakia (Dvorackova et al. 1977). There are circumstantial, but unconfirmed, reports that the occurrence of toxigenic strains of Fusarium and trichothecenes in maize (250-4000 $\mathrm{\mu g}$ 4-deoxynivalenol $/ \mathrm{kg}$ and $1500-10000 \mu \mathrm{g}$ zearalenone $/ \mathrm{kg}$ ) may be aetiological risk factors for oesophageal cancer in the Transkei (Marasas et al. 1979). Fusarium production of $\mathrm{T}-2$ toxin which induces cardiovascular lesions and various types of tumours in the digestive tract and brain of rats (Schoental, 1979) has been speculated as a causal agent for oesophageal cancer in China and South Africa (Stoloff, 1982).

Recent dietary surveys show that the dietary levels of ochratoxin A, 4-deoxynivalenol, sterimatocysin and patulin in the UK are currently negligible, while aflatoxin levels in most susceptible products (with the exception of some peanut products) are generally within the regulatory limits, $\mathrm{AFM}_{1}$ levels in milk and dairy products are $<0.1 \mu \mathrm{g} / \mathrm{kg}$ (Ministry of Agriculture, Fisheries and Food, 1987).

\section{HETEROCYCLIC AMINES (PROTEIN PYROLYSIS PRODUCTS)}

Heterocyclic amines (Fig. 1) constitute an important class of mutagenic and carcinogenic compounds (Table 2) found in cooked and charred foods. The total daily per capita consumption has been estimated to be as high as $100 \mu \mathrm{g}$ (Sugimura, 1985). The specific mutagenic activities of some heterocyclic amine mutagens formed by Maillard-type reactions during high temperature food preparation (in excess of $300^{\circ}$ ) are considerably higher than those for other carcinogenic food contaminants such as PAH, mycotoxins and $\mathrm{N}$-nitroso compounds when tested under the same conditions using TA98 in the Ames Salmonella test.

Under normal cooking conditions, the development of an increased mutagenic 


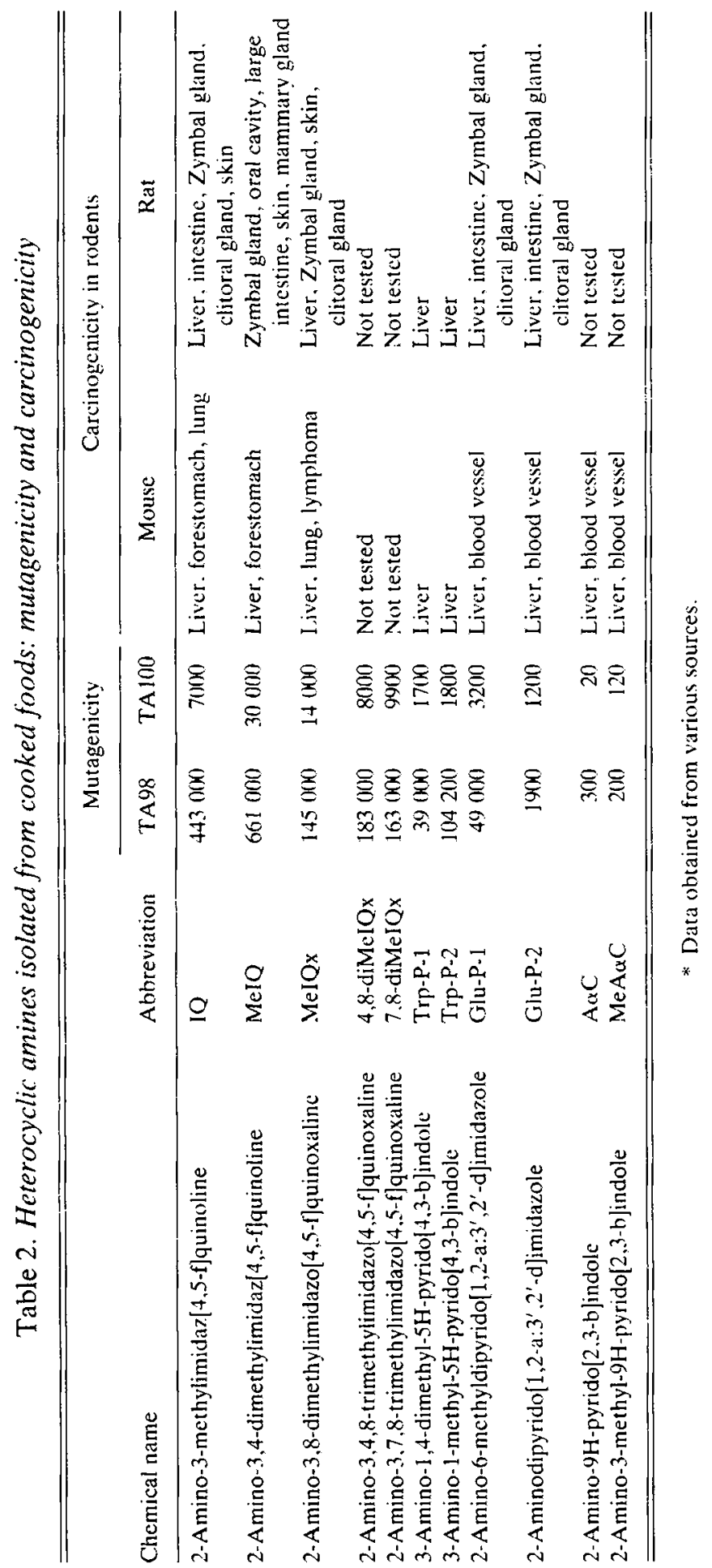


Table 3. Occurrence of heterocyclic amines* in foods $(\mu \mathrm{g} / \mathrm{kg}) \uparrow$

\begin{tabular}{|c|c|c|c|c|c|c|c|c|c|}
\hline Foodstuff & $\mathrm{A} \alpha \mathrm{C}$ & $\mathrm{MeA} \alpha \mathrm{C}$ & Glu-P-1 & Glu-P-2 & IQ & MeIQ & MeIQx & Trp-P-1 & Trp-P-2 \\
\hline Broiled or fricd beef $\S$ & 651 & $63 \cdot 5$ & - & - & $<20 \cdot 1$ & $1-2 \cdot 4$ & 1.5 & $53 \ddagger$ & 1.6 \\
\hline Hamburger & - & - & - & - & 0.02 & $<1.0$ & - & - & - \\
\hline Becf extract|| & - & - & - & - & $<0 \cdot 2$ & $<0 \cdot 2$ & $<69$ & - & $3 \cdot 2$ \\
\hline Worcestershire sauce & - & - & $0 \cdot 1$ & 0.3 & - & - & - & - & - \\
\hline Grilled-broiled chicken & 180 & $15 \cdot 1$ & - & - & - & - & $2 \cdot 1$ & - & - \\
\hline $\begin{array}{l}\text { Broiled sun-dried } \\
\text { sardinef }\end{array}$ & - & - & - & - & 158 & 72 & - & $13 \cdot 3$ & $13 \cdot 1$ \\
\hline $\begin{array}{l}\text { Smoked, dried bonito } \\
\text { (fish) }\end{array}$ & - & 一 & 一 & - & - & - & $2-3$ & - & - \\
\hline $\begin{array}{l}\text { Smoked, dried mackerel } \\
\text { Fried Walleye pollack }\end{array}$ & - & 一 & - & - & - & - & 0.8 & - & - \\
\hline$(\text { fish })^{* *}$ & - & - & - & - & 0.16 & 0.03 & $6 \cdot 4$ & - & - \\
\hline Broiled salmon & - & - & - & - & $<0.4$ & $<0.9$ & - & - & - \\
\hline $\begin{array}{l}\text { Broiled sun-dried } \\
\text { cuttlefish }\end{array}$ & - & - & - & 280 & - & - & - & - & - \\
\hline $\begin{array}{l}\text { Grilled Chinese } \\
\text { mushrooms }\end{array}$ & $47 \cdot 2$ & $5 \cdot 4$ & - & - & - & - & - & - & - \\
\hline Grilled onion & 1.5 & - & - & - & - & - & - & - & - \\
\hline
\end{tabular}

* See Table 2 for full chemical names.

+ Data obtained from several sources.

$\doteqdot$ Expressed on dry weight basis.

$\S$ Also contains $0.5 \mu \mathrm{g} / \mathrm{kg}$ DiMeIQx and $15 \mu \mathrm{g} / \mathrm{kg}$ PhIP.

I. Also contains $<0.3 \mu \mathrm{g} / \mathrm{kg} 4,8$ - and 7,8-DiMeIQx.

If Also contains up to $9 \mu \mathrm{g} / \mathrm{kg}$ Phe-P-1.

** Also contains $0.1 \mu \mathrm{g} / \mathrm{kg}$ 4.8-DiMeIQx and $69 \cdot 2 \mu \mathrm{g} / \mathrm{kg}$ PhIP.

response indicating the formation of mutagens on cooking is largely restricted to protein-rich foods with low carbohydrate and lipid content (Hargraves \& Pariza, 1984). Examples of such foods include baked meat loaf, fried beef, pork and fish, broiled extracts of pork and beef, and broiled fish. Subsequent investigations have shown that these foods are the major dietary sources of heterocyclic amines as summarized in Table 3.

Several carcinogenic heterocyclic amines including Trp-P-1 and Trp-P-2 (Manabe et al . 1987), MeIQx (Yanagisawa et al. 1986) and IQ-type amines have been detected in dialysis fluids, and the accumulation of Glu-P-1 and Glu-P-2 in plasma of patients with uraemia (Manabe et al. 1987) has been reported. The biological monitoring of Trp-P-1 and Trp-P-2 in human plasma (Manabe \& Wada, 1988), and MeIQx in human urine (Murray et al. 1989) show that humans are widely exposed to measurable quantities of these compounds. The fact that microsomal fractions of human liver can convert both MeIQx (Murray et al. 1988) and 2-amino-1-methyl-6-phenylimidazo[4,5-b]pyridine (PhIP) (McManus et al. 1989) to potent mutagens in the Ames Salmonella test, and the fact that N-acetylated metabolic products of Glu-P-1 and Glu-P-2 have been found in human urine, bile, liver and kidney (Kanai et al. 1988) indicate that these compounds may be suspect human carcinogens. However, until more information is obtained about the carcinogenicity of these compounds in dose-response studies, including low exposures, and in animal species other than rats and mice, in which their potency is only 
Table 4. Dietary surveys and daily $N$-nitrosodimethylamine (NDMA) intake

\begin{tabular}{|c|c|c|c|}
\hline Country & $\begin{array}{l}\text { NDMA intake } \\
(\mu \mathrm{g} / \mathrm{d})\end{array}$ & Major NDMA source & Rcference \\
\hline UK & $0.53^{*}$ & Cured meats $(81 \%)$ & Gough et al. (1978) \\
\hline Holland & $0 \cdot 38$ & Beer $(71 \%)$ & Stephany \& Schuller (1980) \\
\hline $\begin{array}{l}\text { W. Germany } \\
(1979-80)\end{array}$ & $\begin{array}{l}1.02 \text { (men) } \\
0.57 \text { (women) }\end{array}$ & $\begin{array}{l}\text { Beer }(65 \%) \\
\text { Cured meats }(10 \%)\end{array}$ & Spiegelhalder et al. (1980) \\
\hline $\begin{array}{l}\text { W. Germany } \\
\text { (1981) }\end{array}$ & $\begin{array}{l}0.53 \text { (men) } \\
0.35 \text { (women) }\end{array}$ & $\begin{array}{l}\text { Beer }(40 \%) \\
\text { Cured meats }(18 \%)\end{array}$ & Spiegelhalder (1983) \\
\hline Japan & 1.8 & Dried fish $(91 \%)$ & Maki et al. (1980) \\
\hline Japan & $0 \cdot 5$ & Fish products $(88 \%)$ & Yamamoto et al. (1984) \\
\hline Sweden & $0 \cdot 29$ & $\begin{array}{l}\text { Meat products }(61 \%) \\
\text { Beer }(30 \%)\end{array}$ & Österdahl (1988) \\
\hline China & No values & Marine foods & Song \& Hu (1988) \\
\hline Italy & No values & Cured meats & Gavinelli et al. (1988) \\
\hline
\end{tabular}

* Beer not included in the survey.

moderate, and more comprehensive information on their occurrence in foods is available, the potential human cancer risk presented by these compounds will be hard to evaluate.

\section{N-NITROSAMINES}

The occurrence of $\mathrm{N}$-nitroso compounds in foodstuffs probably represents the most comprehensively researched exposure situation for any class of genotoxic carcinogenic compounds in the human diet, and has been a subject of recent reviews (Forman, 1987; Tricker \& Preussmann, 1988). The carcinogenic effects of these compounds in experimental animals (Preussmann \& Stewart, 1984) and their relevance to human cancer (Bartsch \& Montesano, 1984) have also been extensively reviewed.

The dietary exposure to $\mathrm{N}$-nitrosodimethylamine (NDMA) and other volatile $\mathrm{N}$ nitrosamines has been calculated in a number of food surveys (Table 4). The major food items most frequently found to contain $\mathrm{N}$-nitroso compounds are cured meats (especially bacon after frying), beer and salt-dried-smoked fish. In cured meats and beer, reductions in the use of nitrates used during curing and modification of malting techniques have resulted in significant reductions in the levels of $\mathrm{N}$-nitroso compounds over the last 5 years. In West Germany, the daily NDMA exposure from beer of $0.74 \mu \mathrm{g} / \mathrm{d}$ in $1979-80$ (Spiegelhalder et al. 1980) has been reduced to $0 \cdot 1 \mu \mathrm{g} /$ day in 1987 (Frommberger, 1989). Thus, the current NDMA exposure levels are probably lower than the values quoted in Table 4.

Volatile $\mathrm{N}$-nitroso compounds represent only a small proportion of the total N-nitroso compound burden. In cured bacon, volatile and non-volatile $\mathrm{N}$-nitroso compounds (Tricker et al. 1984$)$ constitute about $0.45 \%(0.06-1.08 \%)$ and $2.74 \%(0-6.86 \%)$ of the total $\mathrm{N}$-nitroso compounds present respectively (Massey et al. 1988). At least $80 \%$ of the $\mathrm{N}$-nitroso compounds found in cured meats are protein-bound (Tricker et al. 1985), the majority of which appear to be in the form of $\mathrm{N}$-nitrosoproline (Sen et al. 1987). Due to the lack of suitable analytical methods, the exposure to the majority of non-volatile $\mathrm{N}$-nitroso compounds cannot currently be evaluated. However, most non-volatile 
Table 5. Environmental levels and exposure to carcinogenic metals in the $U K^{*}$

\begin{tabular}{|c|c|c|c|c|c|}
\hline \multirow[b]{2}{*}{ Metal } & \multicolumn{3}{|c|}{ Environmental level } & \multicolumn{2}{|c|}{ Adult exposure $(\mu \mathrm{g} / \mathrm{d}) \div$} \\
\hline & $\underset{\left(n g / m^{3}\right)}{\text { Air }}$ & $\begin{array}{l}\text { Water } \\
(\mu \mathrm{g} / \mathrm{l})\end{array}$ & $\begin{array}{l}\text { Total diet } \\
(\mu \mathrm{g} / \mathrm{kg})\end{array}$ & Inhalation & $\begin{array}{c}\text { Total ingestion } \\
\text { diet - water }\end{array}$ \\
\hline Arsenict & $20 \cdot 0$ & $1 \cdot 2$ & $110 \cdot 0$ & 0.04 & $130 \cdot 0$ \\
\hline Chromiums: & $7 \cdot 0$ & $0 \cdot 2$ & $50 \cdot 0$ & 0.14 & $60 \cdot 0$ \\
\hline Vickelf & $20 \cdot 0$ & 8.0 & $130 \cdot 0$ & 0.4 & $170 \cdot 0$ \\
\hline Cadmium & $30 \cdot 0$ & - & $25 \cdot 0$ & 0.6 & $30 \cdot 0$ \\
\hline L.ead & $20(00) \cdot 0$ & $10 \cdot 0$ & $90 \cdot 0$ & $4(0 \cdot 0$ & $180 \cdot 0 \S$ \\
\hline Mercury & $7 \cdot 0$ & - & $4 \cdot 0$ & $0 \cdot 14$ & $15 \cdot 0$ \\
\hline Selenium & $3 \cdot 0$ & $0 \cdot 2$ & $60 \cdot 0$ & 0.06 & $70) \cdot 0$ \\
\hline Tin & $30 \cdot 0$ & 0.04 & $200 \cdot()$ & 0.6 & $2(1) \cdot 0$ \\
\hline Zinc & $3(k) \cdot 0$ & $40 \cdot 0$ & $10000 \cdot 0$ & $6 \cdot 0$ & $10(0) 0 \cdot 0$ \\
\hline
\end{tabular}

\footnotetext{
* Modified data from Bennett (1986).

+ Based on consumption of $1200 \mathrm{~g}$ food/d and 1.21 water/d.

$\div$ Metals for which sufficient evidence is available to show that either the metal or some of its compounds are carcinogenic to man (Sunderman, 1986).

$\$$ Includes $60 \mu \mathrm{g} / \mathrm{d}$ from surface contamination of food.
}

$\mathrm{N}$-nitrosamines found in foods such as $\mathrm{N}$-nitrosoproline and other $\mathrm{N}$-nitrosated amino acids are non-carcinogenic. $\mathrm{N}$-nitrososarcosine is an exception which is an oesophageal carcinogen of moderate potency in rats.

\section{METAL RESIDUES}

Exposure to carcinogenic metals by chronic exposure of low-level metal contaminants, residues or additives in food and water is summarized in Table 5 (Bennett, 1986). Drinking water is usually a secondary source of metal exposure, except in areas where drinking water is collected from mineralized areas or is contaminated by industrial or mining effluent and agricultural residues. Lead contamination is elevated when $\mathrm{Pb}$ piping is used for soft water. Certain foodstuffs show elevated concentrations of particular metals such as mercury accumulation in fish and cadmium in offals and shell fish. Metal accumulation on dust and dirt by atmospheric deposition may provide an important exposure source for $\mathrm{Pb}$. particularly for children eating uncleaned foodstuffs.

There is sufficient epidemiological evidence to show that inorganic and organic arsenic compounds, chromates and certain nickel compounds are carcinogenic to man, and that beryllium and certain organic and inorganic $\mathrm{Pb}$ compounds may be carcinogenic (Sunderman, 1986). The determination of total dietary metal exposure (Table 5) provides a rather misleading evaluation since the total metal content is determined regardless of the oxidation state (free metal, organic or inorganic compounds, or both). In most cases, metal compounds of known carcinogenic potential in animal experiments are not expected to be present in foods (i.e. Ni carbonyls and chromate salts).

\section{FOOD ADDITIVES}

The use of nitrates (and nitrites) as food additives during meat curing and cheese fermentation is often falsely claimed to represent a carcinogenic risk. Ingested nitrate 
per se is not carcinogenic; however, it acts as a precursor to nitrite (via in vivo bacterial reduction) which reacts either directly or indirectly (again via bacteria) to produce genotoxic carcinogenic $\mathrm{N}$-nitroso compounds. As a result, nitrate should be regarded as an 'indirect risk' factor and $\mathrm{N}$-nitroso compounds as a 'direct risk' factor in human carcinogenesis (Preussmann \& Tricker, 1988).

The previously reported carcinogenic potential of saccharin has also been subject to sufficient doubt that it has recently been re-released as an artificial sweetener in the United States.

\section{SYNTHETIC CHEMICALS}

Several synthetic chemicals of known carcinogenic potential occur in a limited range of foodstuffs. In the majority of cases, it is impossible to calculate human exposure and to generalize on susceptible food products. In the case of PCB, analytical studies confirm that most adults carry significant body burdens of PCB in their adipose tissues $(0 \cdot 1-1 \cdot 0$ $\mathrm{mg} / \mathrm{kg}$ ) indicating an earlier widespread environmental exposure to PCB. Current trends show that the contamination of foodstuffs with PCB is minimal, only fresh water fish from aquatic environments with high levels of PCB providing a significant human dietary source of PCB. In animal studies, $\mathrm{PCB}$ can act as carcinogens per se as well as modulators of carcinogenesis by $\mathrm{PAH}$, aflatoxin $\mathrm{B}_{1}$ and $\mathrm{N}$-nitroso compounds. $\mathrm{PCB}$ are probably more likely to be promoters rather than genotoxic initiators of carcinogenesis. This is probably also the case for other polychlorinated industrial chemicals.

Agricultural chemical residues, in particular DDT and chlorinated pesticides, dieldrin, daminozide and several plant fungicides (captan and ethylene thiourea) are still causes for concern in several fruit and vegetable products.

The migration of plasticizers di-2-ethylhexylphthalate (DEHP) and di-2-ethylhexyladipate (DEHA) from food contact materials (PVC wrappings etc.) into food products results in an average daily exposure of about $1600 \mu \mathrm{g} \mathrm{DEHA} / \mathrm{d}$ and $20 \mu \mathrm{g}$ $\mathrm{DEHP} / \mathrm{d}$. As both these compounds only show (probably non-genotoxic) carcinogenicity at very high doses, the human risk from the levels found in foods appears negligible.

The light-dependent formation of ethylcarbamate (urethane) in some stone fruit brandies $(<9000 \mu \mathrm{g} / \mathrm{l})$ is still a cause for concern in a limited range of products. In other alcoholic beverages and fermented foods (bread, yoghurt and cheese), urethane concentrations are low to non-detectable (Dennis et al. 1989). Urethane is a proven carcinogen in several animal species (Schmähl et al. 1977).

\section{CONCLUSIONS}

The contamination of foods by both genotoxic and non-genotoxic carcinogens is a cause for concern, and further attempts to reduce human exposure are warranted. However, the concentrations of known initiating carcinogens in foods are usually low, to very low, and we, therefore, do not support the postulated theory that $30 \%$ of human cancers are caused by the low human exposure to these compounds in the diet. 


\section{REFERENCES}

Arai, M. \& Hibino, T. (1983). Tumorigenicity of citrinin in male F344 rats. Cancer Letters 17, 281-287.

Bartsch, H. \& Montesano, R. (1984). Relevance of nitrosamines to human cancer. Carcinogenesis 5, 1381-1393.

Bennett, B. G. (1986). Exposure assessment for metals involved in carcinogenesis. In Environmental Carcinogens. Selected Methods of Analysis, vol. 8. Some Metals: As, Be, Cd, Cr, Ni, Pb, Se, Zn, pp. 115-127 [I. K. O'Neill, P. Schuller and L. Fishbein, editors]. Lyon: International Agency for Research on Cancer.

Demeke, T., Kidane, Y. \& Wuhib, E. (1979). Ergotism - a report on an endemic. Ethiopian Medical Journal $17,107-113$.

Dennis, M. J., Howarth, N., Key, P. E., Pointer. M. \& Massey, R. C. (1989). Investigation of ethyl carbamate levels in some fermented foods and alcoholic beverages. Food Additives and Contaminants 6, 383-389.

Dennis, M. J., Massey, R. C., McWeeny, D. J. \& Knowles, M. E. (1983). Analysis of polycyclic aromatic hydrocarbons in UK total diets. Food and Chemical Toxicology 21, 569-574.

Doll, R. \& Peto, R. (1981). The causes of cancer: Quantitative estimates of avoidable risks of cancer in the United States today. Journal of the National Cancer Institute 66, 1192-1308.

Dvorackova, I., Kusak, V., Vesely, D., Vesela, J. \& Nesnidal, P. (1977). Aflatoxin and encephalopathy with fatty degradation of viscera (Reye). Annales de la Nutrition et de l'alimentation (Paris) 31, 977-989.

Forman, D. (1987). Dietary exposure to N-nitroso compounds and the risk of human cancer. Cancer Surveys 6 , $719-738$.

Fritz, W. \& Soos, K. (1981). Studies on environmentally-induced contamination of foods with cancerogenic hydrocarbons in the GDR and Hungarian People's Republic. Nahrung 25, 905-913.

Frommberger, R. (1989). N-Nitrosodimethylamine in German beer. Food and Chemical Toxicology 27, 27-29.

Gavinelli, M., Fanelli, R., Bonfanti, M., Davoli, E. \& Airoldi, L. (1988). Volatile nitrosamines in foods and beverages: Preliminary survey of the Italian market. Bulletin of Environmental Contamination and Toxicology 40, 41-46.

Gough, T. A., Webb, K. S. \& Coleman, R. F. (1978). Estimation of the volatile nitrosamine content of UK food. Nature 272, 161-163.

Hargraves, W. A. \& Pariza, M. W. (1984). Mutagens in cooked foods. Journal of Environmental Science and Health C2, $1-49$

International Agency for Research on Cancer (1986). Patulin. In Some Naturally Occurring and Synthetic Food Components, Furocourmarins and Ultraviolet Radiation, pp. 83-89. Lyon: International Agency for Research on Cancer.

Jelinck, C. F., Pohland, A. E. \& Wood, G. E. (1989). Worldwide occurrence of mycotoxins in foods and feeds - an update. Journal of the Association of Official Analytical Chemists 72, 223-230.

Kanai, Y., Manabe, S. \& Wada, O. (1988). In vitro and in vivo $\mathrm{N}$-acetylation of carcinogenic glutamic acid pyrolysis products in humans. Carcinogenesis 9, 2179-2184.

Kanisawa, M. \& Suzuki, S. (1978). Induction of renal and hepatic tumors in mice by ochratoxin A, a mycotoxin. Gann 69, 599-600.

Krishnamachari, K. A. V. R. \& Bhat, R. V. (1977). Poisoning by ergoty bajra (pearl millet) in man. Indian Journal of Medical Research 64, 1624-1628.

Krogh, P. (1980). Ochratoxins: Occurrence, biological effects and causal role in disease. In Natural Toxins, pp. 673-680 [D. Eaker and T. Wadstrom, editors]. Oxford: Pergamon Press.

Lutwick, L. I. (1979). Relation between aflatoxin, hepatitis-B virus, and hepatocellular carcinoma. Lancet $\mathbf{i}$, 755-757.

McManus, M. E., Felton, J. S., Knize, M. G., Burgess, W. E., Roberts-Thomson, S., Pond, S. M., Stupans, I. \& Veronese, M. E. (1989). Activation of the food-derived mutagen 2-amino-1-methyl-6-phenylimido [4,5-b]pyridine by rabbit and human liver microsomes and purified forms of cytochrome P-450. Carcinogenesis 2, 357-363.

Maki, T., Tamaura, Y., Shimamura, Y. \& Navi, Y. (1980). Estimate of the volatile nitrosamine content of Japanese food. Bulletin of Environmental Contamination and Toxicology 25, 257-261.

Manabe, S. H. \& Wada, O. (1988). Analysis of human plasma as an exposure level monitor for carcinogenic tryptophan pyrolysis products. Mutation Research 209, 33-38.

Manabe, S. H., Yanagisawa, S.-B., Guo, S., Abe, S., Ishikawa, Y.\& Wada, O. (1987). Detection of Trp-P-1 and Trp-P-2, carcinogenic tryptophan pyrolysis products, in dialysis fluid of patients with uremia. Muration Research $179,33-40$. 
Marasas, W. F. O., Schalk, J. \& Mirocha, C. J. (1979). Incidence of Fusarium species and mycotoxins, deoxynivalenol and zearalenone, in corn produced in esophageal cancer areas in Transkei. Journal of Agricultural and Food Chemistry 27, 1108-1112.

Massey, R. C., Key, P. E., McWeeny, D. J. \& Tricker, A. R. (1988). Non-volatile N-nitroso compounds in cured meats. In Nutritional and Toxicological Aspects of Food Processing, pp. 73-81 [R. Walker and E. Quattrucci, editors]. London: Taylor and Francis.

Ministry of Agriculture, Fisheries and Food (1987). Mycotoxins. Food Surveillance Paper no. 18. London: H.M. Stationery Office.

Murray, B. P., Boobis, A. R., de la Torre, R., Segura, J. \& Davies, D. S. (1988). Inhibition of dietary mutagen activation by methyl xanthines. Biochemical Society Transactions 16, 620-621.

Murray, S., Gooderham, N. J., Boobis, A. R. \& Davies, D. S. (1989). Detection and measurement of MeIQx in human urine after ingestion of a cooked meat meal. Carcinogenesis 10, 763-765.

Obana, H., Hori, S. \& Kashimoto, T. (1981). Determination of polycyclic aromatic hydrocarbons in marine samples by high-performance liquid chromatography. Bulletin of Environmental Contamination and Toxicology 26, 613-620.

Österdahl, B.-G. (1988). Volatile nitrosamines in foods on the Swedish market and estimation of their daily intake. Food Additives and Contaminants 5, 587-595.

Preussmann, R. \& Stewart, B. W. (1984). N-Nitroso carcinogens. In Chemical Carcinogens. ACS Monograph no. 182, pp. 643-828 [C. E. Searle, editor]. Washington, DC: American Chemical Society.

Preussmann, R. \& Tricker, A. R. (1988). Endogenous nitrosamine formation and nitrate burden in relation to gastric cancer epidemiology. In Gastric Carcinogenesis, ECP Annual Symposium Series, pp. 147-162 [P. I. Reed and M. J. Hill, editors]. Amsterdam: Excerpta Medica.

Santodonato, J., Howard, P. \& Basu, D. (1981). Health and ecological assessment of polynuclear aromatic hydrocarbons. Journal of Environmental Pathology and Toxicology 5, 1-364.

Schmähl, D., Port, R. \& Wahrendorf, J. (1977). A dose-response study on urethane carcinogenesis in rats and mice. International Journal of Cancer 19, 77-80.

Schoental, R. (1979). The role of fusarium mycotoxins in the aetiology of tumours of the digestive tract and certain other organs in man and animals. Frontiers in Gastrointestinal Research 4, 17-24.

Sen, N. P., Baddoo, P. A. \& Seaman, S. W. (1987). The analysis and significance of bound $\mathrm{N}$-nitrosoproline in nitrite-cured meat products. Food Additives and Contaminants 6, 21-28.

Song, P. J. \& Hu, J. F. (1988). N-Nitrosamines in Chinese foods. Food and Chemical Toxicology 26, 205-208.

Spiegelhalder, B. (1983). Vorkommen von Nitrosaminen in der Umwelt. In Das Nitrosamin-Problem, pp. 27-40 [R. Preussmann, editor]. FRG: Verlag Chemie.

Spiegelhalder, B., Eisenbrand, G. \& Preussmann, R. (1980). Volatile nitrosamines in food. Oncology 37. 211-216.

Stephany, R. W. \& Schuller, D. G. (1980). Daily dietary intakes of nitrite, nitrate and volatile N-nitrosamines in the Netherlands using the duplicate sample technique. Oncology 37, 203-210.

Stoloff, L. (1982). Mycotoxins as potential environmental carcinogens. In Carcinogens and Mutagens in the Environment, vol. 1, Food Products, pp. 97-120 [H. F. Stich, editor]. Boca Raton, Florida: CRC Press.

Sugimura, T. (1985). Carcinogenicity of mutagenic heterocyclic amines formed during cooking process. Mutation Research 150, 33-41.

Sunderman, F. W. Jr (1986). Carcinogenicity and mutagenicity of some metals and their compounds. In Environmental Carcinogens. Selected Methods of Analysis, vol. 8, Some Metals: $\mathrm{As}, \mathrm{Be}, \mathrm{Cd}, \mathrm{Cr}, \mathrm{Ni}, \mathrm{Pb}, \mathrm{Se}$, $Z n$, pp. $17-43$ [I. K. O'Neill, P. Schuller and L. Fishbein, editors]. Lyon: International Agency for Research on Cancer.

Tricker, A. R., Perkins, M. J., Massey, R. C., Bishop, C., Key, P. E. \& McWeeny, D. J. (1984). Incidence of some non-volatile $\mathrm{N}$-nitroso compounds in cured meats. Food Additives and Contaminants 1, 245-252.

Tricker, A. R., Perkins, M. J., Massey, R. C. \& McWeeny, D. J. (1985). Some nitrosamino acids in bacon adipose tissue and their contribution to the total $\mathrm{N}$-nitroso compound concentration. Zeitschrift für Lebensmittel-Untersuchung und Forschung 180, 379-383.

Tricker, A. R. \& Preussmann, R. (1988). N-Nitroso compounds and their precursors in the human environment. In Nitrosamines - Toxicology and Microbiology, pp. 88-116 [M. J. Hill, editor]. Chichester: Ellis Horwood Ltd.

Van Rensburg. S. J. (1977). Role of epidemiology in the elucidation of mycotoxin health risks. In Mycotoxins in Human and Animal Health, pp. 699-711 [J. V. Rodericks, C. W. Hesseltine and M. A. Mehlman, editors]. Park Forest South. Illinois: Pathotox Publications. 
Wogan, G. N. \& Newberne, P. M. (1967). Dose response characteristics of aflatoxin $B_{1}$ carcinogenesis in the rat. Cancer Research $27.2370-2373$.

Wynder, E. L. \& Gori, G. B. (1977). Contribution of the environment to cancer incidence: An epidemiological exercise. Journal of the National Cancer Institute 58, 825-832.

Yamamoto, R.. Iwata, R. Ishiwata, H., Yamada, T. \& Tanimura, A. (1984). Determination of volatile nitrosamine levels in foods and estimation of their daily intake in Japan. Food and Chemical Toxicology 22. 61-64.

Yanagisawa, H., Manabe, S., Kitagawa, Y., Ishikawa, S., Nakajima, K. \& Wada, O. (1986). Presence of 2-amino-3,8-dimethylimidazo[4,5-f]quinoxaline (MeIQx) in dialysate from patients with uremia. Biochemical and Biophysical Research Communications 138, 1084-1089. 